\title{
CONFLICT DIRECTIE - ACCOUNTANTS
}

\author{
door Drs. Jac. Krikke
}

In Engeland is in de afgelopen zomer een ernstig conflict ontstaan tussen de directie van een der grote Engelse onroerende goederen maatschappijen, The City of London Real Property Company Ltd., en de accountants van deze vennootschap, de heren Turquand, Youngs \& Co. Het is interessant hiervan het een en ander te memoreren.

De zaak is deze: de vennootschap heeft in begin 1963 een groot minderheidsbelang in een andere onroerende goederen maatschappij, The City \& Victoria Property Company Ltd., overgenomen (in 1959 - bij de oprichting van laatstgenoemde - had zij reeds $51 \%$ van de aandelen van deze vennootschap genomen en het ging nu om de resterende $49 \%$ ). Deze overname werd uitgevoerd door aan de aandeelhouders van de tweede vennootschap $£ 170.600$ gewone aandelen van de eerste vennootschap te geven in ruil voor hun aandelen.

Het bestuur van de eerste vennootschap stond nu op het standpunt dat het verkrijgen van dit belang als volgt in de jaarrekening dient te worden weergegeven: de post „Shares in Subsidiary Companies” op de balans te verhogen met $£ 170.600$, zijnde de nominale waarde van de aandelen, uitgegeven ter verkrijging van de aandelen in City \& Victoria. Hiertegenover zou dan ook $£ 170.600$ worden toegevoegd aan de post ,Share capital”.

De methode van Turquand, Youngs \& Co. was: de post „Shares in Subsidiary Companies" te verhogen met $£ 580.040$, zijnde de marktwaarde - op het moment van uitgifte - van de $\$ 170.600$ aandelen, uitgegeven door de vennootschap; de waarde dus van het overgenomen pakket aandelen. Van de $\$ 580.040 \mathrm{zou}$ - hiertegenover - $\$ 170.600$ geboekt moeten worden als toename van het aandelenkapitaal en het verschil ( $\$ 409.440)$ zou als een vermeerdering moeten worden gebracht naar de kapitaal agio rekening.

De accountants waren van mening dat - bij opvoering van het nominale bedrag de investering in de jaarrekening ondergewaardeerd wordt. Het weergeven van de marktwaarde, zijnde in werkelijkheid de kosten van het verkrijgen van de deelneming, is nodig voor een „true and fair view” van de jaarrekening zoals deze aan aandeelhouders wordt voorgelegd.

Het bestuur wenste echter in de jaarrekening de nominale waarde van de uitgegeven aandelen op te nemen. Het is van oordeel, dat het alleen gaat om een ruil van aandelen en dat de nieuwe aandeelhouders een deel krijgen in het totale bezit, welke situatie ,properly" weerspiegeld wordt door de nominale waarde der aandelen op te voeren. De vennootschap is zich bewust dat de waarde van de eigendommen van City \& Victoria hoger is dan de boekwaarde van $£ 170.600$ aangeeft, maar aangezien zij van tijd tot tijd een herwaardering van haar bezittingen doorvoert, acht zij het onwerkelijk om $n u$ een „kunstmatige" waardering toe te passen.

De directie van de vennootschap was bovendien van mening dat de van dag tot dag fluctuerende marktwaarde geen gezonde basis is om de kosten van de aankoop tot uitdrukking te brengen. De directie zegt ook dat de meningen over de admini- 
stratieve verwerking van transacties als de onderhavige in het bedrijfsleven, maar ook in het accountantsberoep, verdeeld zijn. Beide standpunten „hebben hun gerenommeerde voor- en tegenstanders".

De mening van de directie werd bevestigd toen zij juridisch advies had ingewonnen. De directie voelde zich eveneens gesteund door de, desgevraagde, mening van haar ,consulting accountants”, de heren Cooper Brothers \& Co.

De accountants handhaafden hun standpunt en verklaarden wel een verklaring te zullen afgeven, maar met voorbehoud. De directie wenste dit niet (men zou hier de vraag kunnen stellen of een voorbehoud voor dit t.o.v. de balanstelling slechts kleine bedrag nu werkelijk zo'n overwegend bezwaar was). Zij verklaarde, dat de „omvang en standing van de vennootschap met zich meebrengt dat zij zich niet een verklaring met voorbehoud kan permitteren". Om toch een schone verklaring te krijgen, heeft de direcrie zich „met tegenzin" aan de wens van de accountants geconformeerd, maar daarbij de accountants meegedeeld, dat zij van mening is dat als gevolg van het verschil in opvatting de basis van het wederzijdse vertrouwen tussen haar en de accountants niet meer aanwezig is en dat zij dientengevolge voornemens is de accountants voor hun diensten te bedanken en zij stelt de aandeelhouders - aldus de directie - in hun belang voor een andere controlerende accountant te benoemen (nl. de heren Cooper Brothers \& Co.) *).

Het technische meningsverschil alsmede het punt van het vertrouwen, dat door de directie hieraan is vast geknoopt, zijn aanleiding geweest tot uitvoerige publicaties in "Accountancy", "The Accountant" en andere periodieken. Ondermeer zijn gepubliceerd de jaarstukken van de betrokken vennootschap, de „representations of the auditors”, een ,statement" van het bestuur der betrokken vennootschap, het ingewonnen juridisch advies en een "statement" van het Institute of Chartered Accountants in England and Wales.

Het bijzondere is, dat het geschil in zeer korte tijd een veel wijdere strekking heeft gekregen dan een conflict tussen een accountant en de directie van een door hem gecontroleerde onderneming; de strekking namelijk van de functionele plaats van de accountant tegenover zijn opdrachtgever. Bijzonder is verder, dat de behandeling hiervan zich is gaan voltrekken in het openbaar.

In de eerste plaats heeft de beroepsorganisatie zich snel en intensief op deze zaak beraden. In haar beraad - in een speciaal hiervoor bijeengeroepen bestuursvergadering - heeft zij zich los gemaakt van het technische verschil van opvatting en zich geconcentreerd op het algemene probleem.

Het ontslag van accountants - die ingevolge de Companies Act vertegenwoordigers zijn van de aandeelhouders en aan hen rapporteren - is een ernstige zaak en van grote betekenis voor de aandeelhouders. Het Institute acht het daarom van het grootste belang hierop niet slechts de beroepsgenoten, maar juist ook de andere erbij betrokkenen en - nadrukkelijk - ook het maatschappelijk verkeer in het algemeen, te wijzen op de beginselen, welke naar zijn mening de verhouding tussen een accountant en zijn opdrachtgever bepalen. Om deze reden heeft het Institute

*) "The Accountant" vraagt zich in een zijner commentaren af of het technische meningsverschil niet door de directie als aanleiding is gebruikt tot het voorstel om de relatie met de accountant te verbreken. Aandeelhouders immers zullen zich afvragen in hoeverre de technische kwestie werkelijk zo gewichtig was als de directie doet voorkomen, gezien het feit dat zij toch de balans heeft opgemaakt overeenkomstig de zienswijze van de accountants. 
zijn „statement" aan de pers verstrekt. De ,statement” beschouwt de genoemde verhouding tegen de achtergrond van de grote verantwoordelijkheid die de accountants tegenover het beleggende publiek hebben.

En dan doet de motivering van het directievoorstel tot het bedanken van de ene accountant en het benoemen van een andere, vragen rijzen, ondermeer de vraag of de directie de verhouding accountant-opdrachtgever juist ziet. En dit is beslist niet het geval, aldus het Institute.

Accountants worden door de aandeelhouders benoemd teneinde, in overeenstemming met de voorschriften van de Companies Act, hen te vertegenwoordigen. De accountants hebben de plicht een „critical review” te maken van de jaarstukken zoals deze overgelegd worden door het bestuur van de onderneming en aan de aandeelhouders te rapporteren of deze jaarstukken een ,true and fair view" geven en in overeenstemming zijn met de voorschriften van de Companies Act.

Als de accountants het in belangrijke mate oneens zijn met deze jaarstukken, is het hun plicht dit in hun rapport te zeggen. Als zich dergelijke gevallen voordoen, is dit geen rechtvaardiging om hen te bedanken, tenzij de redenen voor dit bedanken van dien aard zijn, dat de aandeelhouders niet langer vertrouwen hebben in het oordeel, de bekwaamheid of het gedrag van de accountants als hun vertegenwoordigers.

Vertrouwen tussen de directie en de accountants is, hoezeer het uiteraard gewenst is, niet absoluut noodzakelijk voor het verrichten door de accountants van hun controletaak t.b.v. de aandeelhouders. In bepaalde omstandigheden zullen zich onvermijdelijk meningsverschillen tussen de directie en de accountants en een rapport hieromtrent aan de aandeelhouders voordoen.

Het werk van accountants en hun vrijheid om dit in een geest van volledige onafhankelijkheid te doen, kan alleen voortgaan zolang algemeen geaccepteerd wordt, dat een meningsverschil met de directie niet als zodanig een reden is voor de vennootschap om haar accountants te bedanken.

Als het meer zou gaan voorkomen, dat controlerende accountants ontslagen worden wanneer er tussen hen en het bestuur van vennootschappen verschil van mening is over een ,accounting principle", zou dit - aldus het Institute - funest zijn voor het beroep, voor de bedoeling van de wetgever (in de Companies Act) en voor de aandeelhouders, die zich een oordeel moeten vormen over de jaarstukken en het beleid van het bestuur.

Het Engelse Institute heeft door zijn „statement” in dit gewichtige beroepsprobleem richting willen geven, niet slechts tegenover de beroepsgenoten, maar publiekelijk, via de pers.

De actie van het Institute is echter niet de enige welke in het openbaar heeft plaats gevonden.

Ook de „Association of Investment Trusts”, de organisatie der professionele aandeelhouders, heeft er zich over uitgelaten. Deze organisatie heeft namelijk - kort voor de aandeelhoudersvergadering van de City of London Real Property zijn leden (voorzover aandeelhouders van de C.L.R.P.) geadviseerd om tegen het directievoorstel - om van accountant te veranderen - te stemmen.

De wijze van weergave in de jaarrekening is in dit conflict niet het belangrijke punt, aldus de A.I.T., maar de vraag of het voorstel van de directie aan de aandeelhouders gerechtvaardigd was en de A.I.T. is van mening dat dit niet het geval 
is. Zij vat haar zienswijze tenslotte - aldus een publicatie in "Accountancy" van juli 1963 - samen in de volgende woorden:

"The essential independence of an auditor's position will be prejudiced if he has to face dismissal over a disagreement on such an issue".

Twee dagen nadat de genoemde sector van het bedrijfsleven dit standpunt wereldkundig had gemaakt, heeft de directie haar voorstel om van accountant te wisselen, ingetrokken! $\mathrm{Zij}$ deed dit onder de motivering dat, in the light of the conflicting opinions held .... it is the board's view that it would not be desirable for a resolution of this character to become a subject of controversy at the adjourned general meeting on July 15". 